IZA DP No. 2359

Civil War, Crop Failure, and the Health Status of Young Children

Richard Akresh

Philip Verwimp

October 2006 


\title{
Civil War, Crop Failure, and the Health Status of Young Children
}

\author{
Richard Akresh \\ University of Illinois at Urbana Champaign \\ and IZA Bonn \\ Philip Verwimp \\ Institute of Social Studies, The Hague
}

Discussion Paper No. 2359

October 2006

\author{
IZA \\ P.O. Box 7240 \\ 53072 Bonn \\ Germany \\ Phone: +49-228-3894-0 \\ Fax: +49-228-3894-180 \\ E-mail: iza@iza.org
}

\begin{abstract}
Any opinions expressed here are those of the author(s) and not those of the institute. Research disseminated by IZA may include views on policy, but the institute itself takes no institutional policy positions.

The Institute for the Study of Labor (IZA) in Bonn is a local and virtual international research center and a place of communication between science, politics and business. IZA is an independent nonprofit company supported by Deutsche Post World Net. The center is associated with the University of Bonn and offers a stimulating research environment through its research networks, research support, and visitors and doctoral programs. IZA engages in (i) original and internationally competitive research in all fields of labor economics, (ii) development of policy concepts, and (iii) dissemination of research results and concepts to the interested public.
\end{abstract}

IZA Discussion Papers often represent preliminary work and are circulated to encourage discussion. Citation of such a paper should account for its provisional character. A revised version may be available directly from the author. 


\section{ABSTRACT}

\section{Civil War, Crop Failure, and the Health Status of Young Children}

Economic shocks at birth have lasting impacts on children's health several years after the shock. We calculate height for age z-scores for children under age five using data from a Rwandan nationally representative household survey conducted in 1992. We exploit district and time variation in crop failure and civil conflict to measure the impact of exogenous shocks that children experience at birth on their height several years later. We find that girls born after a shock in a region experiencing these events exhibit 0.72 standard deviations lower height for age z-scores and the impact is worse for poor households. There is no impact of these shocks on boys' health status. Results are robust to using household level production and rainfall shocks as alternative measures of crop failure. The analysis also contributes to the debate on the economic conditions prevailing on the eve of the Rwandan genocide.

JEL Classification: I12, J13, O12, O15

Keywords: child health, economic shocks, civil war, rainfall shocks, Africa

Corresponding author:

Richard Akresh

University of Illinois at Urbana Champaign

Department of Economics

1206 South Sixth Street

Wohlers Hall, Room 470E

Champaign, IL 61820

USA

E-mail: akresh@uiuc.edu

\footnotetext{
* We would like to thank the Department of Agricultural Economics at Michigan State University for making the data available and llana Redstone Akresh and seminar participants at the World Bank/PRIO 2006 conference in Oslo, Norway for helpful suggestions.
} 


\section{Introduction}

There is growing concern among economists and practitioners that economic conditions

prevailing in early childhood may have a persistent effect on child health and socioeconomic outcomes later in life. The shock's effect may be such that children cannot catch-up even if they experience subsequent good years at later ages. Policy makers are aware of the distressing link between early childhood and adult well-being, making it one reason why the World Bank and non-governmental organizations view improvements in child health as a top priority.

In this paper, we focus on how exogenous shocks at birth lead to worse health outcomes in the short-run several years after the shock. In particular, we look at the effect of crop failures and civil conflicts on the health of Rwandan children born between 1987 and 1991 . We use an integrated household survey, combining health and agricultural data with event data from reports by non-governmental organizations. We exploit the local nature of the crop failure (confined to provinces in southern Rwanda) and the civil war (confined to provinces in northern Rwanda) to identify the effect of these exogenous shocks on child health, and we use the variation across birth cohorts to capture the child's exposure to the shock. Our approach is to estimate the effect of these shocks on height-for-age while controlling for province of residence, month and year of birth as well as household, infant, and mother characteristics. Our crop failure results are robust to using rainfall or production shocks, which we have for a sub-sample of children.

There is an extensive literature that attempts to measure the impact of economic shocks on future welfare outcomes. ${ }^{1}$ Using Netherlands’ birth registry data, Van den Berg, Lindeboom, and Portrait (2005) find that poor macroeconomic conditions in infancy lead to higher adult

\footnotetext{
${ }^{1}$ This is related to research that explores the association between health and income and the link between childhood conditions and later welfare outcomes (Curry and Hyson, 1999; Case, Lubotsky, and Paxson, 2002). In a paper exploring the role of shocks and income, Frankenberg, Smith, and Thomas (2004) find that richer households are able to smooth consumption and cope with the unanticipated financial crisis that occurred in Indonesia in 1998.
} 
mortality. Almond (2006) finds that individuals who were in utero during the 1918 influenza pandemic experienced as adults lower education attainment, increased rates of physical disability, and lower socioeconomic status compared with other birth cohorts. Alderman, Hoddinott, and Kinsey (2004) use data from Zimbabwe and show that preschool malnutrition has a negative impact on subsequent human capital formation, measured by the number of grades completed. Yamauchi (2006) shows that healthier children in South Africa start school earlier, attain more grades, and repeat fewer classes. Finally, Maccini and Yang (2006) examine the effect of early-life environmental conditions on health and socioeconomic outcomes later in life for Indonesians. They find that higher early-life rainfall leads to improved health, schooling, spousal quality, and socioeconomic status, but the impacts are only for women.

The literature also provides evidence of gender bias in health and socioeconomic outcomes. Rose (1999) shows that when districts experience higher rainfall, the gender bias in infant mortality in India (favoring boys over girls) narrows significantly. Alderman and Gertler (1997) find that demand for girls' medical care is more income and price-elastic than demand for boys’ medical care in rural Pakistani households. Behrman (1988) finds bias in favor of boys in the intra-household allocation of nutrition during the lean season in India. Recent work questions the perceived view that gender bias is more of problem in Asia than Africa. Verwimp and Van Bavel (2005) find evidence that the usual sex differential in child survival (more girls than boys survive infancy) observed in Africa as well as elsewhere changes under severe living conditions. Dercon and Krishnan (2000) find that adults in poor Ethiopian households are unable to smooth their consumption and women bear the brunt of adverse shocks.

This paper establishes the mechanism linking shocks at birth and adult welfare outcomes— just a few years after the shock, children already have significantly lower height for 
age z-scores and this impact may persist into adulthood. By focusing on the short-run impact of these shocks at birth, we are able to pin down more precisely how the shock could translate into adult impacts, something none of the other papers explore. We also explore a type of shock, civil conflicts, that has received surprising little attention in the development literature despite the fact two-thirds of all countries in sub-Saharan Africa experienced armed conflict during the 1980s and 1990s (Miguel, Satyanath, Sergenti, 2004; Bellows and Miguel, 2006). We find that both types of shocks, crop failure and civil conflict, negatively impact children's health, but the role of gender and poverty differs for each shock. With respect to crop failure, girls, from poor households in particular, are severely negatively impacted, but boys (in either poor or rich households) do not experience any negative effects on their height for age z-scores. However, for children that experience a civil conflict, the health status of both boys and girls in rich and poor households are negatively impacted, although the estimates for boys and by wealth levels are not precisely measured.

The paper is also relevant for the audience interested in the economic conditions prevailing on the eve of the Rwandan genocide in 1994 and the poverty-conflict nexus. ${ }^{2}$ Although there is substantial debate over the direction of this relationship, few papers employ microeconomic data from Rwanda to empirically test it (André and Platteau, 1998; Uvin, 1998; Verwimp, 2005). The area of crop failure under investigation in this paper, Gikongoro province, coincides with the area where the first killings and massacres were committed in early April 1994, suggesting a direct link from poverty to conflict. In her seminal book on the genocide, Alison Desforges (1999) describes how the population and the local administration in this area

\footnotetext{
${ }^{2}$ This nexus is discussed in more detail in Justino (2006), where poverty is viewed as both a cause and a consequence of conflict. The civil conflict in the north lead to worse household welfare in terms of child health and the crop failure and resulting poverty in the south contributed to the subsequent genocide.
} 
did not wait for orders from the central government to begin the genocide. Similarly, with the civil war’s progress in the north from 1990 to 1993, the northern population became progressively displaced and ended up in refugee camps around the capital, Kigali, suggesting a direct link from conflict to poverty. These camps were active recruitment areas for the nascent genocidal militia. With data collected in January 1992, our paper shows that already by that time, rural households in the north were not able to protect their children from the negative effects of the civil war.

The remainder of the paper is organized as follows. Section 2 describes the Rwandan setting and how the shock measures are calculated. Section 3 describes the empirical identification strategy and in Section 4, we present the results as well as tests of the robustness of the shock measures. Section 5 concludes.

\section{Data and Empirical Setting}

\subsection{The rural household economy in Rwanda}

Table 1 presents an overview of the Rwandan provinces and shows significant regional differences. For instance, the southern prefectures of Butare and Gikongoro and the western prefectures Kibuye, Cyangugu, and Gisenyi are poorer than the northern, central and eastern prefectures. Previous work has shown that differences in regional and household income can be explained by farm size, soil fertility, suitability of the soil for high yielding crops, rainfall, access to public infrastructure (such as roads and markets), availability of off-farm jobs, and coffee and tea prices for regions growing these crops (Justino and Verwimp, 2006).

Ninety-three percent of Rwanda’s population live in rural areas and nearly all rural households are engaged in farming. On average, households cultivate 0.89 hectares of land, with 
the vast majority of these landholdings being owner operated. Beans, bananas, potatoes and sweet potatoes are the main food staples, although bananas and potatoes are also sold for cash. Coffee is cultivated as purely a cash crop. Farming is labor intensive, primarily using hoes and machetes, and animal traction is non-existent. Women's labor is particularly important in food crop production, while men's labor is crucial in cash crop production and animal husbandry. Half of Rwanda's farmland suffers from moderate to severe erosion and marginal lands once allowed to fallow are now taken into cultivation. The ideal growing conditions for many crops are between the altitude of 1500 and 1700 meters, which explains the high population densities found at this altitude. The average household derives almost 60 percent of its income from subsistence crop production, while 40 percent is from the sum of beer sales, crop sales, off-farm income, and sales of livestock (Kangasniemi, 1998; Clay, Reardon, Kangasniemi, 1998).

\subsection{Crop Failure in the South and Civil War in the North}

In the late 1980s, Rwanda entered a period of economic decline. The country experienced low coffee and tea prices, unfavorable weather conditions, unresolved refugee questions, demographic growth, and mounting corruption. There was also a dramatic drop in yields of all major crops between 1984 and 1991, with the decline for tubers, the main source of calories for poor households, being particularly strong (Clay, 1996). This decline in yields, combined with population growth, led to an average decline in per capita food production of 25 percent (World Bank, 1998). Two distinct events mark this time period. The first is a local crop failure in southern Rwanda in 1989 and the second is an outbreak of civil conflict in northern Rwanda in October $1990 .^{3}$

\footnotetext{
${ }^{3}$ Figure 1 presents a map of Rwanda depicting the crop failure and civil conflict areas.
} 
Several non-governmental organizations documented the extent and severity of the crop failure. In February 1990, the Center for Cooperative Research and Information (known in Rwanda by the French acronym, IWACU), a non-governmental organization working in rural areas, produced a film "Haguma Amagara" meaning "You Only Live Once." The film documents the food crisis in the south and was motivated by the Rwandan government's refusal to acknowledge the local famine. The footage depicts peasants in southern Rwanda with nothing to eat, markets without products, residents deconstructing their houses to sell the parts for food, hungry children and mothers, and adult males who tell the filmmaker they are too weak to work. The film clearly documents hunger in southern Rwanda during the 1988 to 1990 period.

Apart from the film, at least three Rwandan organizations published reports on the food crisis. The first report, written by Bureau Social Urbain-Caritas in Kigali (1990), cites administrative and local sources documenting hunger and starvation in several communes of Butare (Nyakizu, Runyinya) and Gikongoro (Nyamagabe, Karama). ${ }^{4}$ The report measures the number of deaths due to starvation in those communes and confirmed the withdrawal of children from school. Husbands temporarily migrated in search of income and food, crops were stolen at night, and several cases of suicide were reported. In Gikongoro, the report noted that peasants hoped the next coffee harvest would be good or else they would starve to death. The Caritas report concluded there was no longer anything to eat in the south, and peasants were already eating the leaves and roots of plants.

The second report was written by another grass-roots organization, Conseil de Concertation des Organisations d'Appui aux Initiatives de Base (CCOAIB), but the authors were unable to get a copy of this report (Twizeyimana and Uwimana, 1989). The third report

\footnotetext{
${ }^{4}$ Before the genocide, Rwanda's territorial administration was organized in prefectures (provinces), communes (municipalities), sectors, and cells. A commune had on average 50,000 inhabitants.
} 
describes a local agricultural survey of 300 households conducted by the Ministry of Agriculture in several communes in Gikongoro (Gascon, 1992). The report stated that 25 percent of the surveyed households were indigent and female headed households suffered the most. Two of the reports use the term famine to describe the situation in southern Rwanda, and the third speaks of starvation. Factors mentioned that contributed to the crop failure were rainfall variation as well as crop disease.

Kinyamateka, the most prominent independent newspaper in Rwanda, also published information on the food crisis in 1989, making the famine known to the Rwandan public. André Sibomana, editor of the newspaper in 1989, expressed it as follows:

"In 1989, a terrible famine struck the south of the country. There was a natural explanation for this phenomenon, but the authorities did nothing to improve the situation. Worse still, I had evidence that part of the government's assistance which was intended for the population at risk had been diverted. It was a scandal. I decided to publish this information. We were threatened and we were called liars, until I published photographs which were overwhelming. This had an immediate effect. Readers wrote in to express their satisfaction: at last the truth was being told." (Sibomana, 1999)

Based on the film, the non-governmental organizations' reports, and the newspaper articles, we create a variable indicating which regions in Rwanda experienced crop failure during this time period. This crop failure area included all of the communes of Gikongoro province and the communes of Butare province bordering Gikongoro province (see Figure 1).

The civil war is the second crucial event in this period. In October 1990, a group of rebels consisting of Tutsi refugees who left Rwanda during the 1959 to 1962 revolution and their offspring attacked Rwanda from Uganda. What followed was a civil war between the Rwandan armed forces (FAR) and the rebel army (Rwandan Patriotic Front or RPF) in which civilians in the northern provinces of Byumba and Ruhengeri were the main victims. In January 1991, the rebels mounted a surprise attack against the city of Ruhengeri to liberate political prisoners from 
the government prison, and over the course of that year, 100,000 farmers in the north sought refuge in displacement camps (Prunier, 1995). ${ }^{5}$ A report by an international group of human rights experts describes how both forces were responsible for human rights violations (Federation International des Droits de l’Homme, 1993). The report shows that fighters on both sides abducted and killed civilians and pillaged property. ${ }^{6}$ Battles between both armies were paralleled by peace negotiations and third party interventions. Before the war, relative to other regions in Rwanda, these northern provinces were areas of surplus production providing potatoes to the rest of the country. There are no existing household level data on the extent of the disruption to crop production and income generating activities in the north due the war.

In a manner analogous to the crop failure measure, we use these reports to create a variable indicating which regions in Rwanda experienced armed conflict during this time period. The civil war area included parts of the northern provinces of Byumba and Ruhengeri (see Figure 1).

\subsection{Data}

In January 1992, UNICEF financed a survey on the health status of young children and mothers in Rwanda (UNICEF, 1992). The UNICEF survey was nationally representative and collected detailed information on the date of birth and height of every child under age five in 2,496 rural households, yielding 1774 children under age five with complete information in these households. Wealth data, such as the number of livestock, and information about the mother's health and demographic status were also collected.

\footnotetext{
${ }^{5}$ In 1991, the population of Ruhengeri and Buymba was 1.5 million (Recensement Générale de la Population et de l'Habitat). The number of displaced people increased to 300,000 in the subsequent period 1991 to 1993 (Prunier, 1995).

${ }^{6}$ In addition, between 1990 and 1993, the Rwandan government organized small-scale, local massacres that targeted
} 
Height for age is generally accepted as a good indicator of the long-run nutritional status of children (Thomas, Lavy, Strauss, 1996). Children with low height for their age are considered stunted, an indicator of chronic malnutrition. According to Alderman (1993),

"Though a stunted child may have some catch up growth, for the most part, a child whose growth has faltered in the first two years of life will be on a different growth trajectory during the rest of his/her life."

We compute z-scores for each child's height for age, where the z-score is defined as the difference between the value for an individual child and the median value of the reference population (in this case, the United States), divided by the standard deviation of that reference population (Cogill, 2001). On average, across households in all regions of Rwanda, children were two standard deviations below the average height of a child from the United States. However, there were large regional differences across Rwanda. Results in Table 2 show that children's height for age z-scores were lower in regions that experienced crop failure or civil conflict. Compared to the rest of Rwanda, panel A shows that height for age z-scores were 0.206 standard deviations lower in the crop failure regions, and panel B shows that height for age zscores were 0.262 standard deviations lower in the civil war regions. Finally, pooling children in regions that experienced either crop failure or civil war and comparing them with the rest of the country shows that children in the shock regions had 0.257 standard deviations lower height for age z-scores, a difference that is statistically significant at the one percent level.

The UNICEF survey was linked to a prior agricultural survey that ran from October 1988 to September 1991 and was organized by the Rwandan Department of Agricultural Statistics (DSA) and Michigan State University. ${ }^{7}$ The DSA survey was also nationally representative and

Tutsi in regions far from the war front (Fédération Internationale des Droits de l'Homme, 1993).

${ }^{7}$ To ensure survey quality, DSA and UNICEF had one supervisor in the field per prefecture. This supervisor monitored the performance of each of the interviewers in that prefecture. The supervisor collected completed questionnaires, screened for inconsistencies, and went back to the farm households with the interviewers if needed. 
collected agricultural and economic data (including household production, land holdings, and labor inputs) from half of the 2,496 rural households (see Clay, 1996 for additional details about the DSA survey). ${ }^{8}$ For part of our analysis, we use the agricultural DSA survey to isolate the causal mechanism driving the crop failure results seen with the UNICEF data. We examine household level production shocks and their impact on children's height for age z-scores, but given the smaller sampling frame (1248 households) and the three-year window of household production information, we can only examine 473 children under age five.

\subsection{Ethnicity}

Two important points concerning ethnicity in the Rwandan context should be mentioned. First, although Tutsi account for 10 to 15 percent of the Rwandan population, in the northern civil-waraffected provinces, they account for less than three percent. Given the civil war was confined to the north in the period under investigation, we do not expect ethnicity to be a factor influencing our results for the civil war shock.

Second, although Tutsi account for 15 to 20 percent of the population in the southern crop failure provinces, Austin’s (1996) review of the literature did not find evidence of

The office staff made frequent field visits to see how the questionnaires were understood and completed. Data were checked again in the office, both visually for each questionnaire and with the help of data cleaning programs.

${ }^{8}$ There are two caveats on how representative our findings are using the UNICEF data. First, because of the DSA survey's focus on agriculture, households who did not own or cultivate land (mostly young wage laborers no longer living with their parents) were excluded from the sample. Given that these households generally are poorer than average, this may lead to an underestimate of the true effect of poverty on child health. Second, since the UNICEF survey was linked to the prior DSA survey, which was panel data, we are concerned with possible attrition in the DSA sample. All households that were in the DSA agricultural survey as of 1990 are in the UNICEF sample. The main concern is households that were in the DSA sample in October 1988 but dropped out before the 1990 survey. Of all households who were interviewed during the first round of the DSA survey (from October 1988 to March 1989), 96.8 percent of them were still in the sample in 1990. In the crop failure region, only 14 out of 256 households (5.4 percent) dropped out, while in the civil war region, 3 out of 239 households (1.3 percent) dropped out. We did not find any significant differences in observable characteristics between the 17 dropped households and the remaining households in the crop failure and civil war regions. Given the low overall attrition rate and the lack of observable differences, we believe the UNICEF data are representative of the Rwandan population. 
inequality between the Hutu and Tutsi ethnic groups. Similarly, Verwimp (2005) did not find systematic differences between the two ethnic groups in income per adult equivalent, land size, or livestock holdings in several southern provinces. In 1990, there existed no exclusively Hutu or Tutsi villages in Rwanda, both lived as neighbors and were dispersed across the territory of the southern provinces. Thus, we have no a priori reason to believe or expect that Hutu children would be differentially affected by crop failure compared to Tutsi children. In fact, part of the political economy of Rwanda under the Second Republic is that the southern region as a whole, Hutu as well as Tutsi, were disfavored by the government, whose leaders came from the north of Rwanda (Prunier, 1995). This is also the main reason why the government did not deliver aid to the population affected by the crop failure. Further, as neither the UNICEF nor the DSA survey registered the ethnic affiliation of the children, we are unable to test potential ethnic differences.

\section{Empirical Identification Strategy}

To measure the causal impact of economic shocks on children's health, we exploit two sources of variation. The first is district-wide variation in which regions experienced the different types of shocks. As discussed in Section 2.2 above, Gikongoro and parts of Butare province in southern Rwanda experienced severe crop failure in 1988. However, other regions of the country remained unaffected. Likewise, beginning in October 1990, the rebel army under the command of the RPF attacked Rwanda from Uganda and occupied part of the northern region of the country. In the time-frame of the survey, the civil conflict was confined to the northern provinces. The second source of variation is by birth cohort and measures the child's potential exposure to the shock. Children born before the shock will be impacted differently than children born afterwards. 
The identification strategy can be illustrated using a two-by-two difference-in-differences table. Panel A of Table 3 shows average height for age z-scores for children born before and after the crop failure in affected and unaffected regions. The cross-sectional results show that children born prior to October 1988 in the crop failure region exhibited better height for age zscores than children in the rest of the country (a difference of 0.220 standard deviations, although it is not statistically significant). However, in the crop failure region, children born after October 1988 have worse average height for age z-scores than children born before the crop failure and children in the rest of the country. In the crop failure region, relative to children born before October 1988, average height for age falls 0.068 standard deviations. This is in stark contrast to the rest of the country, which experienced an improvement in children's heights of 0.619 standard deviations. Calculating the difference-in-differences estimator shows that children born after 1988 in the crop failure region have 0.687 standard deviations lower height for age z-scores compared to children in the rest of the country, a result that is significant at the one percent level. The difference-in-differences result can be interpreted as the impact of the crop failure on children's height for age z-scores under the assumption that, without the crop failure, children in the crop failure region born after October 1988 would have experienced the same change in average height for age z-scores as children in the rest of the country.

The results in Panel B of Table 3 analyzing the impact of armed conflict are not as significant as the crop failure results, although controlling for province and birth cohort fixed effects in the regressions in Table 5 yields significant results. Children born in the civil war region prior to the conflict have worse height for age z-scores on average than children in the rest of the country ( 0.223 standard deviations lower). Children from the civil war region born after the war started in October 1990 have improved height for age z-scores but they do not improve 
as much as children born after October 1990 in the rest of the country. The difference-indifferences result indicates that children born after October 1990 in the civil war region have 0.393 standard deviations lower height for age z-scores than children in the rest of the country.

To further explore these preliminary results, in Table 4, we examine whether the impact of crop failure depends on the child's gender. Panel A shows the results for the 855 boys in the sample and Panel B presents the results for the 919 girls. Boys and girls born after October 1988 in the rest of the country experience similar improvements in average height for age z-scores with an increase of 0.579 standard deviations for boys and 0.658 standard deviations for girls. However, the gender difference in the crop failure region is stark. In the crop failure region, boys born after the crop failure have a slightly improved height for age z-score (0.176 standard deviations higher), whereas comparable girls have much worse health status. These girls have a height for age z-score that is 0.286 standard deviations lower than girls born before the crop failure in the same region. The difference-in-differences estimate shows that the impact of the crop failure for girls is a 0.944 standard deviation reduction in height for age z-scores and the result is significant at the one percent level.

\section{Empirical Results}

\subsection{Effect of Crop Failure and Civil War Shocks}

While the difference-in-differences results are revealing and informative, they do not incorporate all available information. To address this issue, we estimate a province and birth cohort fixed effects regression which is comparable to the difference-in-differences estimator. In the simplest specification (additional child and maternal controls are added later), we estimate the following regression: 


$$
H A Z_{i j t}=\alpha_{j}+\beta_{1}\left(\text { ShockRegion }_{j} * \text { BornAfterShock }_{t}\right)+\delta_{t}+\varepsilon_{i j t}
$$

where $H A Z_{i j t}$ is the height for age z-score for child $i$ in region $j$ who was born in time period $t, \alpha_{j}$ are the region fixed effects, $\delta_{t}$ are the cohort of birth (year and month) fixed effects, ShockRegion $_{j} *$ BornAfterShock $_{t}$ indicates children born in a region that experienced a crop failure or civil war after the economic shock occurred, and $\varepsilon_{i j t}$ is a random, idiosyncratic error term. The coefficient $\beta_{1}$ measures the impact of crop failure or civil conflict on children's health status for children born after the shock in regions experiencing these events. Identification of the impact comes from comparing children born before and after the shock occurred and from comparing regions impacted by the shock to the rest of Rwanda.

In Table 5, we present results from estimating variations of equation 1. All regressions include province and birth cohort controls. In column 1, we combine the two types of shocks into a single variable indicating children born in periods after a shock occurred in those regions that experienced either a crop failure (southern region) or a civil conflict (northern region). Results show that children impacted by the shock have 0.390 standard deviations lower height for age z-scores and the result is significant at the five percent level. Column 2 uses a shock variable that only measures whether children were exposed to civil war (similar to Panel B in Table 3). Children born after the civil war affected their region have 0.623 standard deviations lower height for age z-scores, a reduction that is statistically significant at the five percent level. However, in column 3, we do not find a significant impact of the crop failure shock on children's health. Children born in the southern regions after the crop failure experience 0.285 standard deviations lower height for age but the coefficient does not significantly differ from zero.

In all regressions, we included controls measuring characteristics about the mother and these variables all have the expected sign. Healthier mothers, as measured by a woman's body 
mass index, have children with better height for age z-scores. A child whose mother received prenatal care has an increase of 0.336 standard deviations in their height for age $\mathrm{z}$-score, while mothers who are literate have children who are 0.145 standard deviations higher in terms of height for age z-scores. These three coefficients are all significant at the five percent level. In addition, a mother who is married (as opposed to being divorced, widowed, separated, or never married) is correlated with children having 0.216 standard deviations higher height for age zscores, and a mother who gives birth when she is not a teenager has children having higher height for age z-scores.

Although we find a large negative impact of the civil war, the results in Table 6 indicate that not all children experience this shock equally. Girls are much more susceptible to the negative impacts of these shocks than boys. The combined shock measure of crop failure and civil war shocks shows that girls experience 0.723 standard deviations lower height for age zscores (column 2). Columns 3 to 6 present the results for boys and girls for each shock separately. Boys born after the civil war shock were 0.352 standard deviations worse in height for age z-scores but the coefficient is not significantly different from zero. However, girls born after the shock experienced 0.813 standard deviations lower height for age z-scores and the coefficient is significant at the 10 percent level. Results for the crop failure shock (in columns 5 and 6) indicate that only girls are negatively impacted and the coefficient is significant at the five percent level.

We extend this analysis to examine how wealth might mitigate the negative impacts of these shocks on children's health. As owning livestock in this context is both an asset and a sign of wealth, we measure wealth in terms of tropical livestock units (TLU) owned by the household 
and cattle ownership. ${ }^{9}$ For the first measure, households owning less than or equal to one tropical livestock unit, which is a cumulative measure of the number of cattle, pigs, sheep, and goats, are considered to be poor and 77.4 percent of households are classified this way. For the second measure, households owning less than or equal to one cow are considered poor and this represents 87.8 percent of all households.

In Table 7, column 1, the coefficient on the variable that combines crop failure and civil war indicates that poor households are less able to protect their children from these shocks, exhibiting 0.441 or 0.375 standard deviations lower height for age z-scores using the two different wealth measures respectively. However, this negative impact is borne entirely by girls in poor households who experience 0.929 or 0.751 standard deviations lower height for age zscores depending on the wealth measure, and both coefficients are statistically significant at the one percent level (column 3). For rich households, there does not appear to be any significant impact of the combined shock measure. When we restrict the shock measure to civil war, we find a negative impact for rich and poor households, but the coefficients are not statistically significant. In the context of the civil war in northern Rwanda, (the absence of) wealth is not the decisive element in the protection of children from the impact of the war. Notably, this is not the case for crop failure as girls from poor households bear the brunt of the crop failure shock.

In Figures 2 to 4, we extend the regression analysis to examine the nonparametric relationship between height for age z-scores and children's birth cohort. We estimate a kernelweighted local polynomial regression of height for age z-score on birth cohort using an Epanechnikov kernel. Figure 2 compares children in the crop failure regions with children in the rest of the country. We observe that after October 1988, there is a significant drop in height for

\footnotetext{
9 The conversion from different types of livestock to Tropical Livestock Units is calculated as follows: 1 cow $=1$ tlu; 1 pig $=0.25$ tlu; 1 sheep $=0.17$ tlu; and 1 goat $=0.17$ tlu.
} 
age z-scores among children in the crop failure region. However, the impact of the shock is short lived, only affecting children born between October 1988 and July 1989. Figures 3 and 4 distinguish these results by gender, confirming that girls bore the brunt of the crop failure shock. In the crop failure region, girls born between October 1988 and July 1989 experience the lowest height for age z-scores, worse than other girls in the same birth cohort born in the rest of the country. Their height for age z-scores are also lower than boys in the same birth cohort born in the same region and in the rest of the country. A second crop failure in the subsequent agricultural year (beginning October 1989) negatively impacted boys more than girls.

\subsection{Robustness Tests: Household Production and Rainfall Shocks}

To this point in the analysis, we have relied on regional-level measures of the shock variables that were derived from the reports produced at the time of these crises by various nongovernmental organizations or by academic authors. In this section, agricultural production and rainfall data provide us with alternative measures to analyze the impact of the crop failure shock. ${ }^{10}$ We first use the DSA agricultural survey, which was administered to a subset of the UNICEF households, and which contains household-level production information for October 1988 to September 1991. Using this production information, we can estimate the direct impact of a production shock experienced at the time of birth by a child's household on the child's health. Since the production data only cover three years, we exclude children born outside the three year time interval. Of the 921 children under age five in the DSA households, there were 534 born between October 1988 and September 1991. An additional 61 children could not be

\footnotetext{
${ }^{10}$ To our knowledge, no household level measures of the impact of the civil war in the north of Rwanda in the 1990 to 1991 period exist that are sufficiently disaggregated (i.e. number of casualties, property damaged) and cover the entire region.
} 
included in the regressions due to missing data on household production in the year of the child's birth. The smaller sample of households in the DSA survey, the reduced number of birth cohorts to examine, and missing production data for some households reduce the sample of children we can use in the regressions to 473 children. This smaller, but still nationally representative sample of children provides insight into the mechanism driving the earlier crop failure results.

Second, we use rainfall data collected by Rwandan Meteorological Service. These data are available on a monthly basis for each province up to 1991, but collection stopped in four provinces at the start of the civil war. Collection was uninterrupted in the area affected by crop failure. In the regressions using rainfall data, we lose 151 children born in 1991 in the four provinces that stopped collecting rainfall data.

In Table 8, we present the robustness tests. We define the household production shock as the difference between the value of farm output during the year the child is born and the three year average of farm output. A positive value for this variable indicates production in the year of the child's birth is higher than the three year average production (i.e. a positive production shock). Results in column 1 indicate that households that experienced positive production shocks at the time a child was born have children with better height for age z-scores (measured several years after the shock), and the coefficient is significant at the ten percent level.

In column 2, we estimate a reduced form specification using dummy variables for the rain shock—large negative, normal (somewhat negative or somewhat positive) and large positive —-we find that child health improves when the rainfall shock is average or very positive. ${ }^{11}$ Compared to a large negative rainfall shock, children born in years experiencing

\footnotetext{
${ }^{11}$ We use the deviation of annual rainfall from the historical long-run province average as our shock measure. Approximately half of the children experience rainfall shocks categorized as normal and approximately a quarter experience large negative or large positive rainfall shocks, respectively.
} 
normal rainfall exhibit 0.293 standard deviations higher height for age z-scores (significant at the five percent level) and children born in years with large positive rainfall shocks show 0.491 standard deviations higher height for age z-scores (significant at the one percent level). Column 3 presents the result of an instrumental variables specification were we use the rainfall shocks as an instrument for our crop failure shock variable. The result further strengthens our previous findings. Variation in rainfall is the exogenous shock explaining crop failure which in turn affects child health.

\section{Conclusion}

An extensive literature in labor and development economics finds that economic shocks around the time of birth generally have significant negative long-run impacts on adult welfare outcomes. In this paper, by focusing on the short-run impact of these shocks, we try to understand the mechanism by which shocks at birth impact future adult outcomes. We specifically focus on the height for age of children under five years old and find that these economic shocks have lasting impacts several years after the event. Using nationally representative household survey data collected in January 1992 in Rwanda (prior to the 1994 genocide), we exploit variation in the timing and location of localized crop failure and civil conflict across regions of the country and variation in the birth cohort of children who are exposed to the shock. This exogenous variation allows us to measure the causal impact of the shocks these children experience at birth on their height several years later. We find that rural households in areas affected by either crop failure or civil conflict are unable to protect their offspring from the impact of these shocks. Girls are particularly vulnerable in regions that experience crop failure, with girls in poor households bearing the brunt of the impact. We find no evidence of a negative impact of crop failure on the 
health status of boys or children in rich households. However, all children exposed to the civil war shock are negatively impacted, although the estimates for boys and by poverty levels are not precisely measured.

We test the robustness of the crop failure results using two alternative measures. First, using alternative survey data on household level agricultural production for a sub-sample of these households, we confirm that positive crop production shocks improve a child's height for age z-score. Second, we use the deviation of rainfall from the long-run province average to show that positive rainfall shocks are correlated with improved height for age z-scores. We also use an instrumental variables approach to demonstrate the causal mechanism running from rainfall shocks to crop failure to child health. The findings are robust to these alternative specifications.

These results have direct policy implications as they indicate the importance of a quick response to economic crises on the part of governments and non-governmental organizations. Children, in particular girls, are at risk of a worsened health status only a few years after birth due to their household experiencing an economic shock when they were born. Evidence in the literature suggests that a child who has shorter than normal height by age five will not be able to catch-up later in life. The negative shock experienced at birth will likely have long-run consequences for these affected children, leading to worse adult outcomes in terms of health, education, and socioeconomic status. The evidence suggests that helping these children with early interventions may have a larger payoff than the present benefit to only short-run health. 


\section{References}

Alderman, H., 1993. New Research on Poverty and Malnutrition: What are the Implications for Policy? In Including the Poor, M. Lipton and J. van der Gaag, Editors. The World Bank, Washington DC.

Alderman, H., and Gertler, P., 1997. Family Resources and Gender Differences in Human Capital Investments: The Demand for Children's Medical Care in Pakistan. In Intrahousehold Resource Allocation in Developing Countries: Models, Methods and Policy. L. Haddad, J. Hoddinott and H. Alderman, Editors. Baltimore: The Johns Hopkins University Press.

Alderman, H., Hoddinott, J., and Kinsey, B., 2004. Long Term Consequences of Early Childhood Malnutrition. Households in Conflict Network Working Paper 9.

Almond, D., 2006. Is the 1918 Influenza Pandemic Over? Long-Term Effects of In Utero Influenza Exposure in the Post-1940 U.S. Population. Journal of Political Economy, 114(4), 672-712.

André, C., and Platteau, J.P., 1998. Land Relations under Unbearable Stress: Rwanda Caught in the Malthusian Trap. Journal of Economic Behavior and Organization, 34(1), pp.1-47.

Austin, G., 1996. The Effects of Government Policy on the Ethnic Distribution of Income and Wealth in Rwanda: A Review of Published Sources. London School of Economics, manuscript.

Behrman, J.R, 1988. Intrahousehold Allocation of Nutrients in Rural India: Are Boys Favored? Do Parents Exhibit Inequality Aversion? Oxford Economic Papers, 40(1), 32-54.

Bellows, J., and Miguel, E., 2006. War and Institutions: New Evidence from Sierra Leone. American Economic Review, 96(2), 394-399.

Bureau Social Urbain-Caritas, 1990. Les Retombées de la Famine dans les Préfectures de Butare et de Gikongoro. Kigali, Rwanda. February, 26 pages.

Case, A., Lubotsky, D., and Paxson, C., 2002. Economic Status and Health in Childhood: The Origins of the Gradient. American Economic Review, 92(5), 1308-1334.

Clay, D., 1996. Promoting Food Security in Rwanda Through Sustainable Agricultural Productivity: Meeting the Challenges of Population Pressure, Land Degradation and Poverty. International Development Paper No. 17, Michigan State University, Departments of Agricultural Economics and Economics.

Clay, D., Reardon, T., and Kangasniemi, J., 1998. Sustainable Intensification in the Highland Tropics: Rwandan Farmers' Investments in Land Conservation and Soil Fertility. Economic Development and Cultural Change, 46(2), 351-377. 
Cogill, B., 2001. Anthropometric Indicators Measurement Guide. Food and Nutrition Technical Assistance, Academy for Educational Development, Washington, D.C.

Currie, J., and Hyson, R., 1999. Is the Impact of Health Shocks Cushioned by Socioeconomic Status? The Case of Low Birthweight. American Economic Review, 89(2), 245-250.

Dercon, S., and Krishnan, P., 2000. In Sickness and in Health: Risk Sharing Within Households in Rural Ethiopia. Journal of Political Economy, 108(4), 688-727.

Desforges, A., 1999. Leave None to tell the Story. Human Rights Watch, New York.

Fédération Internationale des Droits de l'Homme, 1993. Rapport sur la Commission d'enquête sur les violations des droits de l'Homme au Rwanda depuis le $1^{\mathrm{er}}$ Octobre 1990. ParisNew York, Africa Watch.

Frankenberg, E., Smith, J., and Thomas, D., 2004. Economic Shocks, Wealth and Welfare. Journal of Human Resources, 38(2), 280-321.

Gascon, J.F., 1992. Pauvreté a Gikongoro, Résultats de l'enquête réalisée auprès des ménages indigents. Projet de Développent Agricole de Gikongoro, Document de travail, No.156, June, 62 pages.

Justino, P., 2006. On the Links between Violent Conflict and Chronic Poverty: How Much Do We Really Know? Chronic Poverty Research Centre, University of Manchester, manuscript.

Justino, P., and Verwimp, P., 2006. Poverty Dynamics, Violent Conflict and Convergence in Rwanda. Households in Conflict Network Working Paper 16.

Kangasniemi, J., 1998. People and Bananas on Steep Slopes. Agricultural Intensification and Food Security under Demographic Pressure and Environmental Degradation. Doctoral Dissertation, Agricultural Economics Department, Michigan State University.

Maccini, S., and Yang, D., 2006. Under the Weather: Health, Schooling, and Socioeconomic Consequences of Early-Life Rainfall. University of Michigan, manuscript.

Miguel, E., Satyanath, S., Sergenti, E., 2004. Economic Shocks and Civil Conflict: An Instrumental Variables Approach. Journal of Political Economy, 114(4), 725-753.

Prunier, G., 1995. Rwanda: History of a Genocide. New York, Columbia Press.

Recensement Générale de la Population et de l’Habitat en 1991. 1994 Service Nationale de Recensement. Ministère du Plan et de la Coopération, Kigali. 
Reyntjens, F., 1994. L'Afrique des Grands Lacs en Crise, Rwanda et Burundi (1988-1994). Paris, Karthala.

Rose, E., 1999. Consumption Smoothing and Excess Female Mortality in Rural India. Review of Economics and Statistics, 81(1), 41-49.

Sibomana, A., 1999. Hope for Rwanda, Conversations with Laure Guilbert and Hervé Deguine. Pluto Press, 22 pages.

Thomas, D., Lavy, V., and Strauss, J., 1996. Public Policy and Anthropometric Outcomes in the Cote D’Ivoire. Journal of Public Economics, 61(2), 155-192.

Twizeyimana, P., and Uwimana, V., 1989. Portrait de la Pénurie Alimentaire Actuelle au Rwanda: Dévoilement d'une Famine Cachée sous la Verdure. CCOAIB. Kigali, Rwanda. November, 43 pages.

UNICEF, 1992. Statut Nutritionnel et Sécurité Alimentaire au Rwanda. Résultats de l'Enquête Nationale sur la Nutrition et la Sécurité Alimentaire des Enfants de 0 à 5 Ans et Leurs Mères. Kigali, Rwanda.

Uvin, P., 1998. Aiding Violence: The Development Enterprise in Rwanda. West Hartford, Kumarian Press.

van den Berg, G., Lindeboom, M., and Portrait, F., 2006. Economic Conditions Early in Life and Individual Mortality. American Economic Review, 96 (1), 290-302.

Verwimp, P., 2005. An Economic Profile of Peasant Perpetrators of Genocide: Micro-level Evidence from Rwanda, Journal of Development Economics, 77(2), 297-323.

Verwimp, P., and van Bavel, J., 2005. Child Survival and Fertility of Refugees in Rwanda after the Genocide. European Journal of Population, Special Issue of the Demography of Violent Conflict, 21(2-3), 271-290.

World Bank, 1998. Rwanda Poverty update. Africa Document, annex I.

Yamauchi, F., 2006. Early Childhood Nutrition, Schooling and Sibling Inequality in a Dynamic Context: Evidence from South Africa. International Food Policy Research Institute, Food Consumption and Nutrition Division, Discussion Paper, Washington DC, January. 
Figure 1: Map of Rwanda Indicating Civil War and Crop Failure Regions

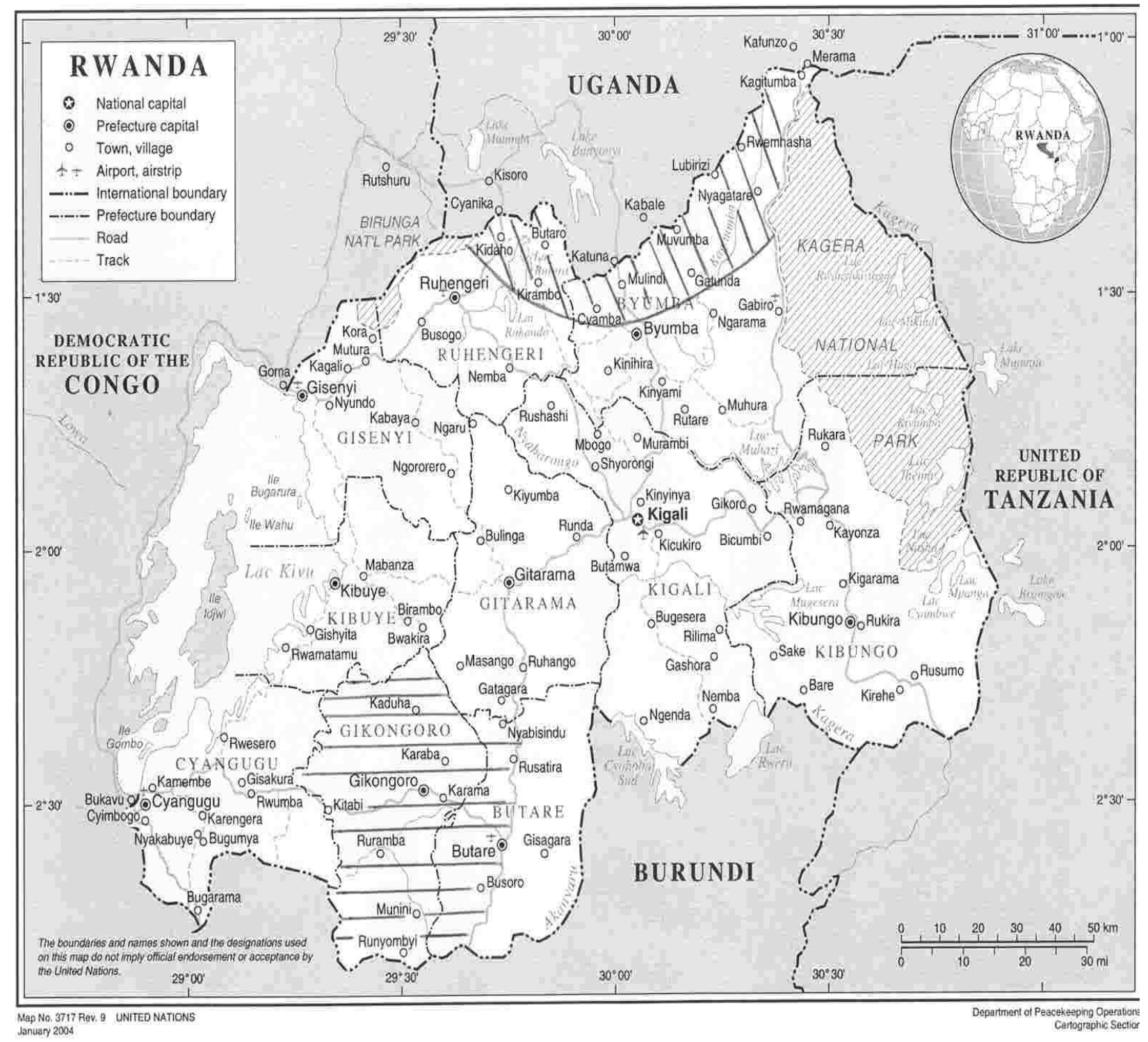

Note: The shaded area in the south which includes Gikongoro prefecture and the part of Butare prefecture bordering Gikongoro was affected by a crop failure which started in October 1988. Information source for this are the NGO reports mentioned on pages 7 and 8. The shaded region in the north, bordering Uganda, was affected by the civil war in the period October 1990 to December 1991. Information source for this is Reyntjens (1994). We remark that the latter area expanded in the 1992-1994 period as the RPF troops advanced their positions in Byumba prefecture. That advance however took place after the collection of the UNICEF data which we use in our study. 
Figure 2: Height for Age Z-Scores By Region and Birth Cohort

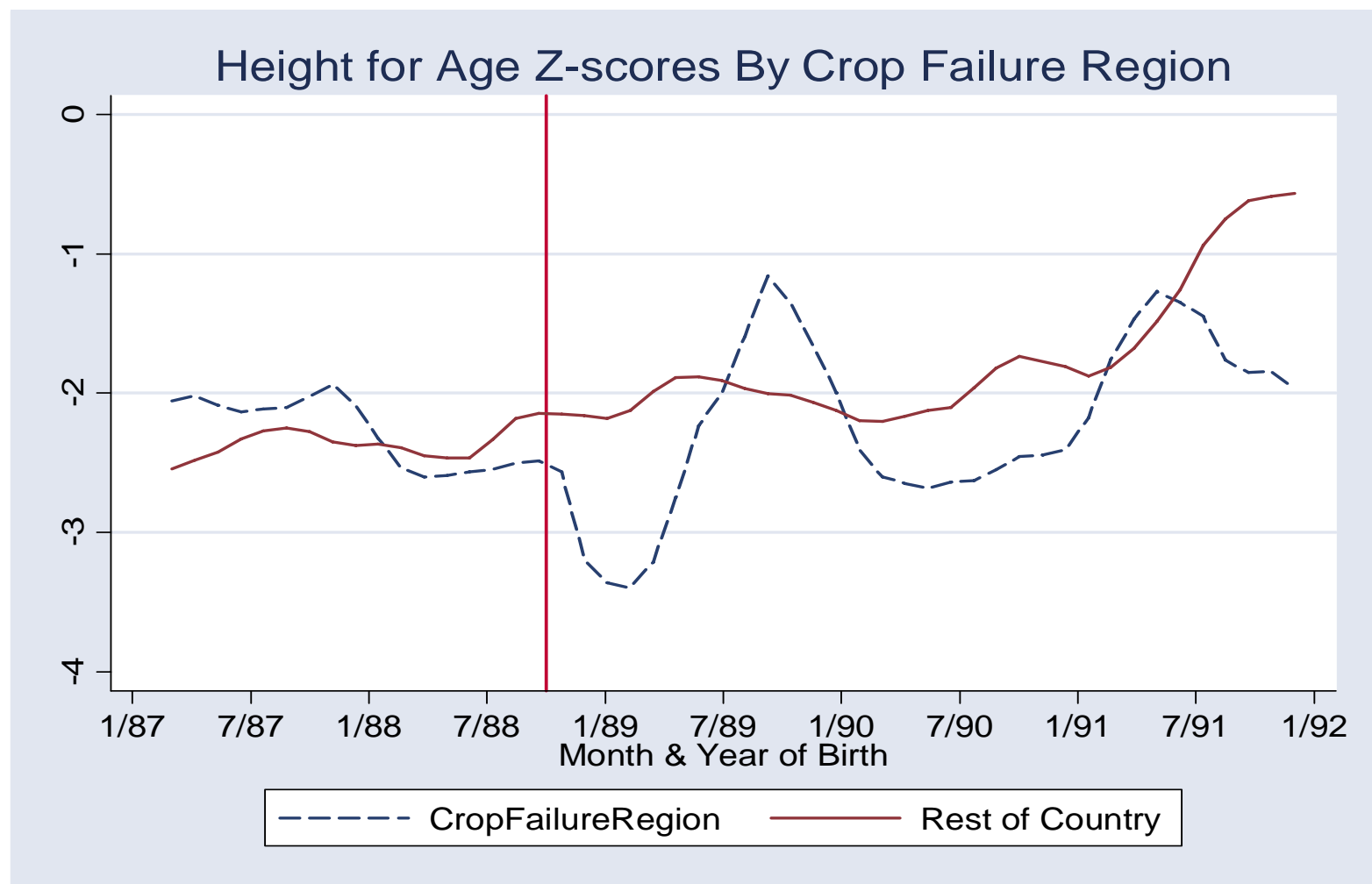

Notes: Kernel-weighted local polynomial regression (using Epanechnikov kernel) of height for age zscore on birth cohort. Vertical line drawn at October 1988, start of crop failure in crop failure regions. Data source: Survey conducted by UNICEF, the Rwandan Department of Agricultural Statistics, and Michigan State University. 
Figure 3: Height for Age Z-Scores By Region, Gender, and Birth Cohort

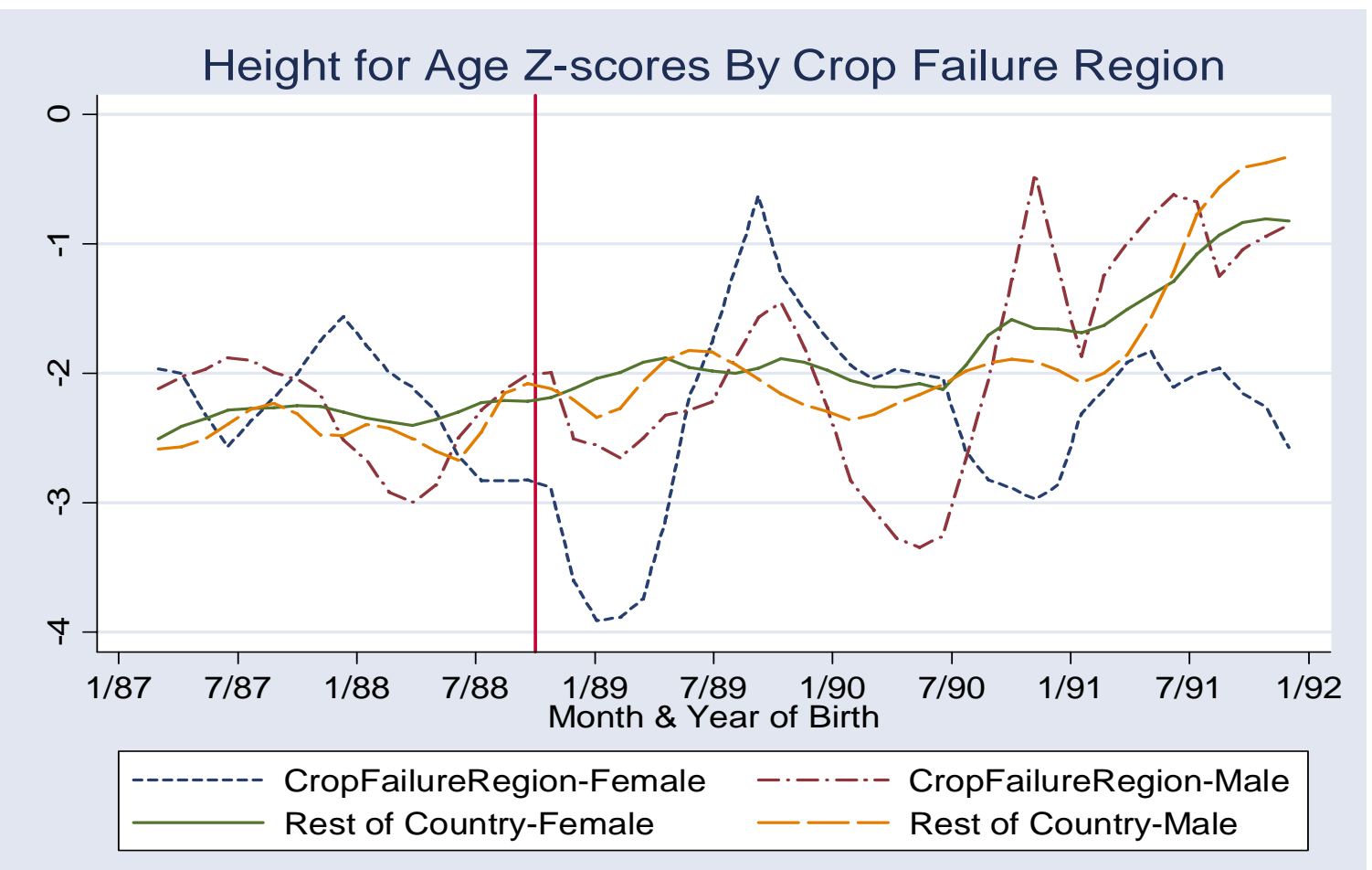

Notes: Kernel-weighted local polynomial regression (using Epanechnikov kernel) of height for age zscore on birth cohort. Vertical line drawn at October 1988, start of crop failure in crop failure regions. Data source: Survey conducted by UNICEF, the Rwandan Department of Agricultural Statistics, and Michigan State University. 
Figure 4: Height for Age Z-Scores By Region, Gender, and Birth Cohort
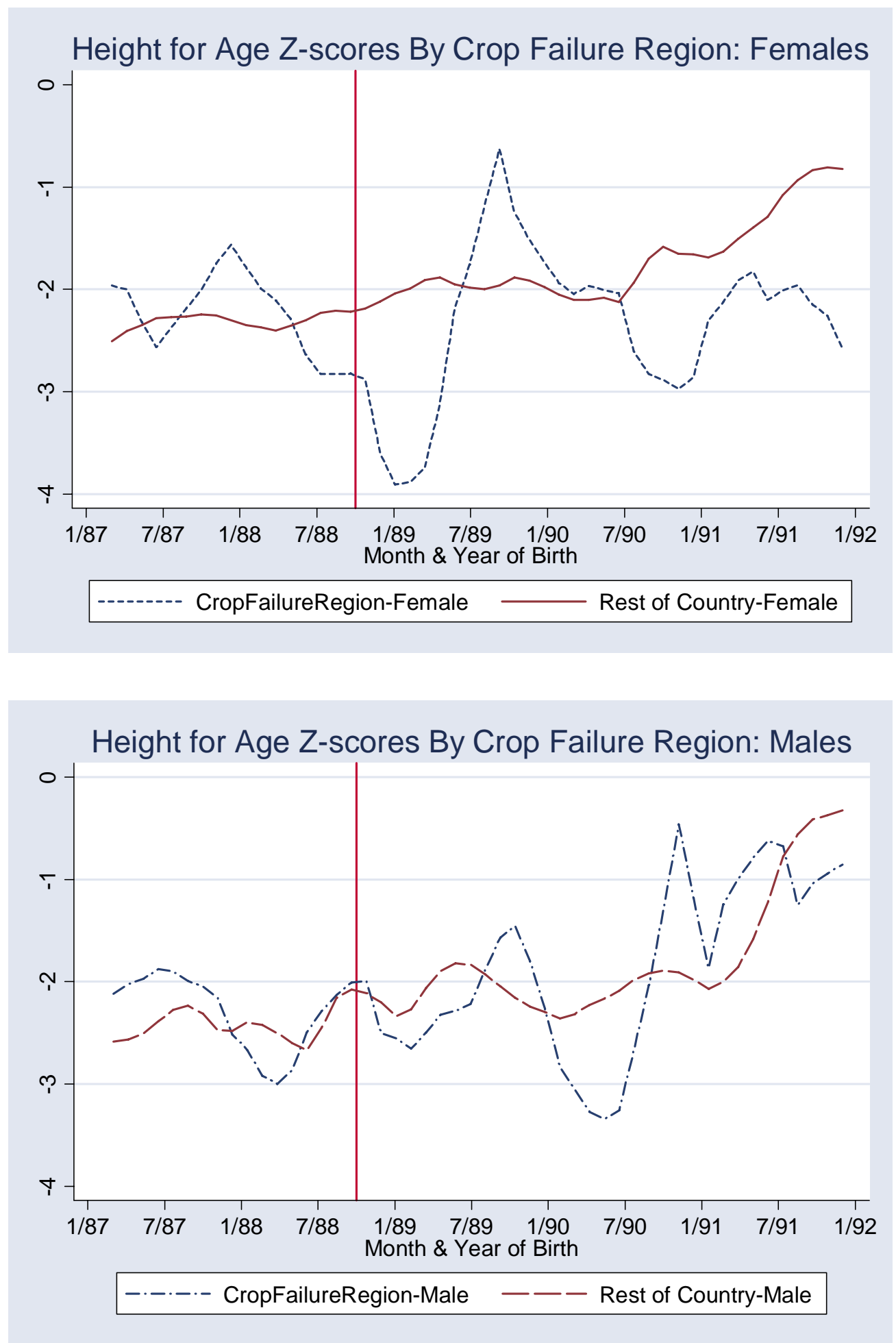

Notes: Kernel-weighted local polynomial regression (using Epanechnikov kernel) of height for age zscore on birth cohort. Vertical line drawn at October 1988, start of crop failure in crop failure regions. Data source: Survey conducted by UNICEF, the Rwandan Department of Agricultural Statistics, and Michigan State University. 
Table 1: Overview of Regional Differences in Rwanda

\begin{tabular}{lllll}
\hline \hline Province & $\begin{array}{l}\text { Average Land Size } \\
\text { per Household } \\
\text { (hectares) }\end{array}$ & $\begin{array}{l}\text { Value of } \\
\text { Production }\end{array}$ & $\begin{array}{l}\text { Altitude } \\
\text { (meters) }\end{array}$ & $\begin{array}{l}\text { Historical Rainfall } \\
\text { Average 1960- } \\
1987 \text { (in mm/year) }\end{array}$ \\
\hline Butare & 0.81 & 36000 & 1660 & 1217 \\
Buymba & 1.01 & 45700 & 1888 & 1271 \\
Cyangugu & 0.66 & 32200 & 1917 & 1559 \\
Gikongoro & 0.89 & 21400 & 1917 & 1436 \\
Gisenyi & 0.45 & 33000 & 1946 & 1263 \\
Gitarama & 0.92 & 50000 & 1630 & 1136 \\
Kibungo & 1.35 & 65500 & 1469 & 1019 \\
Kibuye & 1.16 & 25700 & 2100 & 1311 \\
Kigali & 0.95 & 67500 & 1581 & 1088 \\
Ruhengeri & 0.79 & 45200 & 2115 & 1276 \\
& & & & \\
\hline Rural Rwanda & 0.89 & 44300 & 1802 & 1258 \\
\hline
\end{tabular}

Notes: Crop failure occurred in certain districts in Gikongoro and Butare provinces in October 1988. Civil conflicts occurred in certain districts in Byumba and Ruhengeri provinces starting in October 1990. Data source: Survey conducted by UNICEF, the Rwandan Department of Agricultural Statistics and Michigan State University. Rainfall and altitude information collected by Rwandan Meteorological Service.

${ }^{\text {a }}$ Average value of household crop production from 1989 to 1991 in Rwandan Francs. 
Table 2: Summary Statistics Examining Regions Affected by Civil War and Crop Failure

\begin{tabular}{lllll} 
Panel A: & All Regions & $\begin{array}{l}\text { Crop Failure } \\
\text { Region } \\
(2)\end{array}$ & $\begin{array}{l}\text { Rest of } \\
\text { Country }\end{array}$ & Difference \\
& $(1)$ & -2.197 & -1.991 & $(2)-(3)$ \\
\hline Average Height for Age Z-score & -2.016 & {$[0.141]$} & {$[0.039]$} & {$[0.118]$} \\
& {$[0.038]$} & 216 & 1558 &
\end{tabular}

Panel B:

\begin{tabular}{lllll} 
& All Regions & $\begin{array}{l}\text { Civil War } \\
\text { Region } \\
(2)\end{array}$ & $\begin{array}{l}\text { Rest of } \\
\text { Country } \\
(3)\end{array}$ & Difference \\
& $(1)$ & -2.257 & -1.995 & $-0.262^{*}$ \\
\hline Average Height for Age Z-score & -2.016 & {$[0.102]$} & {$[0.041]$} & {$[0.139]$} \\
& {$[0.038]$} & & & \\
Number of children & 1774 & 146 & 1628
\end{tabular}

Panel C:

\begin{tabular}{lllll} 
& All Regions & $\begin{array}{l}\text { Crop Failure } \\
\text { \& Civil War } \\
\text { Regions }\end{array}$ & $\begin{array}{l}\text { Rest of } \\
\text { Country }\end{array}$ & Difference \\
& $(1)$ & $(2)$ & $(3)$ & $(2)-(3)$ \\
\hline Average Height for Age Z-score & -2.016 & -2.221 & -1.964 & $-0.257 * * *$ \\
& {$[0.038]$} & {$[0.094]$} & {$[0.042]$} & {$[0.095]$} \\
Number of children & 1774 & 362 & 1412 & \\
\hline
\end{tabular}

Notes: Standard errors in brackets. * significant at 10\%; ** significant at 5\%; *** significant at $1 \%$. Crop failure region denotes districts in Gikongoro and Butare provinces, while civil war region denotes districts in Byumba and Ruhengeri provinces. Additional details on the geographic coding of these variables are provided in the paper. Data source: Survey conducted by UNICEF, the Rwandan Department of Agricultural Statistics and Michigan State University. 
Table 3: Difference in Differences Comparing Height for Age Z-Scores for Children Born Before and After the Crop Failure (Panel A) and Children Born Before and After the Civil War (Panel B)

\begin{tabular}{lll|l}
\hline Panel A: & $\begin{array}{l}\text { Crop Failure } \\
\text { Region } \\
(\mathrm{n}=216)\end{array}$ & $\begin{array}{l}\text { Rest of } \\
\text { Country } \\
(\mathrm{n}=1558)\end{array}$ & Difference \\
\hline Born Before Crop Failure Shock & -2.158 & -2.378 & 0.220 \\
& {$[0.217]$} & {$[0.059]$} & {$[0.179]$} \\
Born After Crop Failure Shock & -2.226 & -1.759 & -0.467 \\
& {$[0.204]$} & {$[0.054]$} & {$[0.161]$} \\
\hline Difference & -0.068 & 0.619 & $-0.687^{* * *}$ \\
& {$[0.287]$} & {$[0.084]$} & {$[0.235]$}
\end{tabular}

Panel B:

\begin{tabular}{lll|l} 
& $\begin{array}{l}\text { Civil War } \\
\text { Region } \\
(\mathrm{n}=146)\end{array}$ & $\begin{array}{l}\text { Rest of } \\
\text { Country } \\
(\mathrm{n}=1628)\end{array}$ & Difference \\
\hline Born Before Civil War & -2.411 & -2.188 & -0.223 \\
& {$[0.112]$} & {$[0.043]$} & {$[0.152]$} \\
Born After Civil War & -1.683 & -1.067 & -0.616 \\
& {$[0.233]$} & {$[0.114]$} & {$[0.362]$} \\
\hline Difference & 0.728 & 1.121 & -0.393 \\
& {$[0.242]$} & {$[0.103]$} & {$[0.333]$}
\end{tabular}

Notes: Standard errors in brackets. * significant at $10 \%$; ** significant at 5\%; *** significant at $1 \%$. Crop failure region denotes districts in Gikongoro and Butare provinces and the crop failure shock occurred in October 1988. Civil war region denote districts in Byumba and Ruhengeri provinces and civil conflict started in October 1990. Data source: Survey conducted by UNICEF, the Rwandan Department of Agricultural Statistics and Michigan State University. 
Table 4: Difference in Differences Comparing Height for Age Z-Scores for Boys (Panel A) and Girls (Panel B) Born Before and After the Crop Failure

\begin{tabular}{lll|l}
\hline \hline Panel A: Boys (n=855) & $\begin{array}{l}\text { Crop Failure } \\
\text { Region } \\
(\mathrm{n}=106)\end{array}$ & $\begin{array}{l}\text { Rest of } \\
\text { Country } \\
(\mathrm{n}=749)\end{array}$ & Difference \\
\hline Born Before Crop Failure Shock & -2.205 & -2.381 & 0.176 \\
& {$[0.282]$} & {$[0.090]$} & {$[0.248]$} \\
& & & \\
Born After Crop Failure Shock & -2.029 & -1.802 & -0.227 \\
& {$[0.282]$} & {$[0.077]$} & {$[0.238]$} \\
& & & \\
\hline Difference & 0.176 & 0.579 & -0.403 \\
& {$[0.388]$} & {$[0.123]$} & {$[0.336]$}
\end{tabular}

Panel B: Girls (n=919)

\begin{tabular}{lll|l} 
& $\begin{array}{l}\text { Crop Failure } \\
\text { Region } \\
(\mathrm{n}=110)\end{array}$ & $\begin{array}{l}\text { Rest of } \\
\text { Country } \\
(\mathrm{n}=809)\end{array}$ & Difference \\
\hline Born Before Crop Failure Shock & -2.103 & -2.376 & 0.273 \\
& {$[0.336]$} & {$[0.089]$} & {$[0.260]$} \\
Born After Crop Failure Shock & -2.389 & -1.718 & -0.671 \\
& {$[0.291]$} & {$[0.077]$} & {$[0.220]$} \\
\hline Difference & & & \\
& -0.286 & 0.658 & $-0.944^{* * *}$ \\
& {$[0.427]$} & {$[0.114]$} & {$[0.331]$}
\end{tabular}

Notes: Standard errors in brackets. * significant at 10\%; ** significant at 5\%; *** significant at $1 \%$. Crop failure region denotes districts in Gikongoro and Butare provinces and the crop failure shock occurred in October 1988. Data source: Survey conducted by UNICEF, the Rwandan Department of Agricultural Statistics and Michigan State University. 
Table 5: Province-Birth Cohort Fixed Effects Regressions Measuring the Impact of Civil War and Crop Failure on Children's Height for Age Z-Scores

\begin{tabular}{|c|c|c|c|}
\hline Dependent Variable: Children's Height for Age Z-Score & (1) & (2) & (3) \\
\hline Shock Region * Born After Shock & $\begin{array}{l}-0.390^{* *} \\
{[0.167]}\end{array}$ & & \\
\hline Civil War Region * Born After Shock & & $\begin{array}{l}-0.623 * * \\
{[0.308]}\end{array}$ & \\
\hline Crop Failure Region * Born After Shock & & & $\begin{array}{l}-0.285 \\
{[0.196]}\end{array}$ \\
\hline \multicolumn{4}{|l|}{ Mother's Characteristics } \\
\hline Mother's Body Mass Index & $\begin{array}{l}0.029 * * \\
{[0.014]}\end{array}$ & $\begin{array}{l}0.030^{* *} \\
{[0.014]}\end{array}$ & $\begin{array}{l}0.030 * * \\
{[0.014]}\end{array}$ \\
\hline Child Received Prenatal Care & $\begin{array}{l}0.336^{* *} \\
{[0.136]}\end{array}$ & $\begin{array}{l}0.354 * * * \\
{[0.136]}\end{array}$ & $\begin{array}{l}0.331^{* *} \\
{[0.136]}\end{array}$ \\
\hline Mother Married & $\begin{array}{l}0.216^{*} \\
{[0.127]}\end{array}$ & $\begin{array}{l}0.225^{*} \\
{[0.127]}\end{array}$ & $\begin{array}{l}0.220^{*} \\
{[0.127]}\end{array}$ \\
\hline Mother Literate & $\begin{array}{l}0.145^{* *} \\
{[0.078]}\end{array}$ & $\begin{array}{l}0.144^{*} \\
{[0.078]}\end{array}$ & $\begin{array}{l}0.151^{*} \\
{[0.078]}\end{array}$ \\
\hline $20<=$ Mother's Age $<30$ & $\begin{array}{l}0.264 \\
{[0.186]}\end{array}$ & $\begin{array}{l}0.271 \\
{[0.186]}\end{array}$ & $\begin{array}{l}0.274 \\
{[0.186]}\end{array}$ \\
\hline $30<=$ Mother's Age $<40$ & $\begin{array}{l}0.403^{* *} \\
{[0.189]}\end{array}$ & $\begin{array}{l}0.407 * * \\
{[0.189]}\end{array}$ & $\begin{array}{l}0.413^{* *} \\
{[0.189]}\end{array}$ \\
\hline Mother's Age $>=40$ & $\begin{array}{l}0.210 \\
{[0.217]}\end{array}$ & $\begin{array}{l}0.235 \\
{[0.217]}\end{array}$ & $\begin{array}{l}0.221 \\
{[0.218]}\end{array}$ \\
\hline Number of children & 1774 & 1774 & 1774 \\
\hline
\end{tabular}

Notes: Standard errors in brackets. * significant at 10\%; ** significant at 5\%; *** significant at $1 \%$. All regressions include province and birth cohort controls. The variable Shock Region * Born After Shock indicates children born in periods following when a region experienced either crop failure or civil conflict. The omitted categories for mother's characteristics include mother's age less than 20 years old and mother not married (includes divorced, widowed, separated, never married). Data source: Survey conducted by UNICEF, the Rwandan Department of Agricultural Statistics and Michigan State University. 
Table 6: Province-Birth Cohort Fixed Effects Regressions Measuring the Impact of Civil War and Crop Failure on Children's Height for Age Z-Scores, By Gender

\begin{tabular}{|c|c|c|c|c|c|c|}
\hline $\begin{array}{l}\text { Dependent Variable: } \\
\text { Children's Height for Age Z-Score }\end{array}$ & $\begin{array}{l}\text { Male } \\
(1)\end{array}$ & $\begin{array}{l}\text { Female } \\
(2)\end{array}$ & $\begin{array}{l}\text { Male } \\
\text { (3) }\end{array}$ & $\begin{array}{l}\text { Female } \\
(4)\end{array}$ & $\begin{array}{l}\text { Male } \\
(5)\end{array}$ & $\begin{array}{l}\text { Female } \\
(6)\end{array}$ \\
\hline Shock Region * Born After Shock & $\begin{array}{l}-0.068 \\
{[0.251]}\end{array}$ & $\begin{array}{l}-0.723 * * * \\
{[0.237]}\end{array}$ & & & & \\
\hline Civil War Region * Born After Shock & & & $\begin{array}{l}-0.352 \\
{[0.458]}\end{array}$ & $\begin{array}{l}-0.813^{*} \\
{[0.445]}\end{array}$ & & \\
\hline Crop Failure Region* Born After Shock & & & & & $\begin{array}{l}0.052 \\
{[0.296]}\end{array}$ & $\begin{array}{l}-0.667 * * \\
{[0.277]}\end{array}$ \\
\hline Number of children & 855 & 919 & 855 & 919 & 855 & 919 \\
\hline
\end{tabular}

Notes: Standard errors in brackets. * significant at 10\%; ** significant at 5\%; *** significant at $1 \%$. All regressions include province and birth cohort controls as well as the following mother's characteristics: mother's body mass index, child received prenatal care, mother's martial status, mother's literacy, and mother's age. The variable Shock Region * Born After Shock indicates children born in periods following when a region experienced either crop failure or civil conflict. Data source: Survey conducted by UNICEF, Rwandan Department of Agricultural Statistics and Michigan State University. 
Table 7: Province-Birth Cohort Fixed Effects Regressions Measuring the Impact of Civil War and Crop Failure on Children's Height for Age Z-Scores, By Household Wealth and Gender

\begin{tabular}{|c|c|c|c|c|c|c|}
\hline \multirow{2}{*}{ Dependent Variable: Children’s Height for Age Z-Score } & \multicolumn{3}{|c|}{ Poor HH } & \multicolumn{3}{|c|}{ Rich HH } \\
\hline & $\begin{array}{l}\text { All } \\
(1)\end{array}$ & $\begin{array}{l}\text { Male } \\
\text { (2) }\end{array}$ & $\begin{array}{l}\text { Female } \\
\text { (3) }\end{array}$ & $\begin{array}{l}\text { All } \\
(4)\end{array}$ & $\begin{array}{l}\text { Male } \\
\text { (5) }\end{array}$ & $\begin{array}{l}\text { Female } \\
\text { (6) }\end{array}$ \\
\hline \multicolumn{7}{|l|}{ Panel A Wealth Measure: Tropical livestock units owned by HH } \\
\hline Shock Region* Born After Shock & $\begin{array}{l}-0.441 * * \\
{[0.211]}\end{array}$ & $\begin{array}{l}-0.090 \\
{[0.320]}\end{array}$ & $\begin{array}{l}-0.929 * * * \\
{[0.301]}\end{array}$ & $\begin{array}{l}0.088 \\
{[0.390]}\end{array}$ & $\begin{array}{l}0.499 \\
{[0.561]}\end{array}$ & $\begin{array}{l}-0.619 \\
{[0.651]}\end{array}$ \\
\hline Civil War Region * Born After Shock & $\begin{array}{l}-0.498 \\
{[0.386]}\end{array}$ & $\begin{array}{l}-0.447 \\
{[0.565]}\end{array}$ & $\begin{array}{l}-0.569 \\
{[0.593]}\end{array}$ & $\begin{array}{l}-1.342 \\
{[1.220]}\end{array}$ & $\begin{array}{l}-0.739 \\
{[1.710]}\end{array}$ & $\begin{array}{l}-3.146 \\
{[2.047]}\end{array}$ \\
\hline Crop Failure Region* Born After Shock & $\begin{array}{l}-0.406 \\
{[0.249]}\end{array}$ & $\begin{array}{l}0.077 \\
{[0.385}\end{array}$ & $\begin{array}{l}-1.029 * * * \\
{[0.346]}\end{array}$ & $\begin{array}{l}0.252 \\
{[0.412]}\end{array}$ & $\begin{array}{l}0.662 \\
{[0.599]}\end{array}$ & $\begin{array}{l}-0.334 \\
{[0.682]}\end{array}$ \\
\hline Number of children $^{\text {a }}$ & 1221 & 601 & 620 & 357 & 167 & 190 \\
\hline \multicolumn{7}{|l|}{ Panel B Wealth Measure: Number of cows owned by HH } \\
\hline Shock Region* Born After Shock & $\begin{array}{l}-0.375 * \\
{[0.196]}\end{array}$ & $\begin{array}{l}-0.154 \\
{[0.292]}\end{array}$ & $\begin{array}{l}-0.751 * * * \\
{[0.281]}\end{array}$ & $\begin{array}{l}0.149 \\
{[0.568]}\end{array}$ & $\begin{array}{l}-0.244 \\
{[0.979]}\end{array}$ & $\begin{array}{l}0.121 \\
{[1.071]}\end{array}$ \\
\hline Civil War Region * Born After Shock & $\begin{array}{l}-0.566 \\
{[0.365]}\end{array}$ & $\begin{array}{l}-0.401 \\
{[0.541]}\end{array}$ & $\begin{array}{l}-0.752 \\
{[0.542]}\end{array}$ & $\begin{array}{l}-0.650 \\
{[1.914]}\end{array}$ & $\begin{array}{l}-1.055 \\
{[2.222]}\end{array}$ & N/A \\
\hline Crop Failure Region* Born After Shock & $\begin{array}{l}-0.291 \\
{[0.229]}\end{array}$ & $\begin{array}{l}-0.052 \\
{[0.345]}\end{array}$ & $\begin{array}{l}-0.732 * * \\
{[0.326]}\end{array}$ & $\begin{array}{l}0.220 \\
{[0.587]}\end{array}$ & $\begin{array}{l}-0.045 \\
{[1.034]}\end{array}$ & $\begin{array}{l}0.121 \\
{[1.071]}\end{array}$ \\
\hline Number of children $^{\text {a }}$ & 1386 & 674 & 712 & 192 & 94 & 98 \\
\hline
\end{tabular}

Notes: Standard errors in brackets. * significant at 10\%; ** significant at 5\%; *** significant at $1 \%$. Each coefficient in the table is from a separate regression where the dependent variable is height for age z-score and the independent variable is either shock region*born after shock, civil war region*born after shock, or crop failure region*born after shock. All regressions also include province and birth cohort controls as well as the following mother's characteristics: mother's body mass index, child received prenatal care, mother's martial status, mother's literacy, and mother's age. In Panel A, households that own less than or equal to 1 tropical livestock unit are considered poor (77.4 percent of all households). In Panel B, households that own less than or equal to 1 cow are considered poor (87.8 percent of all households). Data source: Survey conducted by UNICEF, the Rwandan Department of Agricultural Statistics and Michigan State University.

a 196 children are dropped from the 1774-observation regressions because of missing values for household wealth measures. Results for the regressions in previous tables using this 1578 observation sample are similar. 
Table 8: Regressions Measuring the Impact of Alternative Crop Failure Shock Measures on Children’s Height for Age Z-Scores

\begin{tabular}{llll}
\hline \hline Dependent Variable: Children’s Height for Age Z-Score & $\begin{array}{l}\text { DSA Agricultural } \\
\text { Production Sample }\end{array}$ & $\begin{array}{l}\text { UNICEF Sample } \\
\text { All Children }\end{array}$ & $\begin{array}{l}\text { UNICEF Sample } \\
\text { All Children } \\
\text { IV specification } \\
\text { (3) }\end{array}$ \\
\hline
\end{tabular}

Household Production Shock $\quad 0.011^{*}$

[0.006]

Normal Rainfall Deviation

$0.293 * *$

[0.125]

Large Positive Rainfall Deviation

$0.491 * * *$

[0.175]

Crop Failure Region* Born After Shock ${ }^{b}$

$-2.971 * *$

[1.298]

\begin{abstract}
Number of children
$473^{\mathrm{a}}$

$1623^{\mathrm{c}}$

$1623^{\mathrm{c}}$

Notes: Standard errors in brackets. * significant at 10\%; ** significant at 5\%; *** significant at 1\%. All regressions also include province and birth cohort controls as well as the following mother's characteristics: mother's body mass index, child received prenatal care, mother's martial status, mother's literacy, and mother's age. Household production shock is defined as the difference between the value of farm output during the year the child is born and the 3-year average farm output. A larger value for this variable indicates production in the year of the child's birth is higher than the 3 year average production (i.e. a positive production shock). In column 2, dummy variables are created to measure whether rainfall deviations (annual rainfall minus the long-run historical province average) were large positive rainfall shocks, large negative rainfall shocks, or normal rainfall years. The omitted category is large negative rainfall shock. Data source: Survey conducted by UNICEF, the Rwandan Department of Agricultural Statistics and Michigan State University.

${ }^{a}$ DSA production data were only collected between October 1988 and September 1991 and only for a sub-sample of the UNICEF surveyed households, leaving only 473 children with complete information on the household production shock at the time of birth.

${ }^{\mathrm{b}}$ Crop Failure Region * Born After Shock is treated as endogenous and instrumented for with dummy variables measuring rainfall shock deviations (large positive rainfall shock, normal rainfall year, large negative rainfall shock).

${ }^{\mathrm{c}}$ In columns 2 and 3, 151 children are dropped from the 1774-observation regressions because rainfall data were not collected in 4 provinces in 1991. Results for the regressions in previous tables using this 1623 observation sample are similar.
\end{abstract}

